\title{
Discussion on the Key Issues of Strategic Management of Corporate Social Responsibility in China
}

\author{
Jing Li, Hongtao Guo* \\ College of Economics and Management, Shangqiu Normal University, Shangqiu, China \\ Email: *ght1126@163.com
}

How to cite this paper: $\mathrm{Li}, \mathrm{J}$. and Guo, H.T. (2018) Discussion on the Key Issues of Strategic Management of Corporate Social Responsibility in China. Open Journal of Business and Management, 6, 944-952. https://doi.org/10.4236/ojbm.2018.64069

Received: October 7, 2018

Accepted: October 26, 2018

Published: October 29, 2018

Copyright (C) 2018 by authors and Scientific Research Publishing Inc. This work is licensed under the Creative Commons Attribution International License (CC BY 4.0).

http://creativecommons.org/licenses/by/4.0/

\begin{abstract}
The main reason for the unsatisfactory performance of Chinese corporate social responsibility practice is that corporate managers still have different degrees of misunderstanding about corporate social responsibility. It is of great significance to clarify the existing problems in the management of corporate social responsibility and put forward scientific strategic management methods of corporate social responsibility.
\end{abstract}

\section{Keywords}

Strategic Management, Strategic Corporate Social Responsibility, Path Selection, Balance Principle, Process Principle

\section{Introduction}

Since the end of the last century, when the theory of corporate social responsibility was introduced into China, scholars from academic circles, business circles, and government departments have made useful exploration. However, so far, there has been no consensus on what corporate social responsibility is, whether companies should bear social responsibility, and how companies should bear social responsibility. Theoretical differences have led to great differences in the performance of Chinese corporate social responsibility. The Third, Fourth and Fifth Plenary Sessions of the Eighteen separately put forward the policy proposals of "taking social responsibility as the focus, further deepening the reform of state-owned enterprises", "strengthening corporate social responsibility legislation", and "enhancing national awareness, awareness of the rule of law, and awareness of social responsibility", which puts forward higher requirements for CSR practice. With the gradual advancement of the Chinese market econo- 
my, the contradiction between environmental pollution and labor conflicts has become increasingly prominent, and the internal and external environments enterprises face have undergone major changes. In front of enterprises, it is no longer a question of "whether to fulfill social responsibility" but "how to fulfill social responsibility". The emergence of these problems poses a serious challenge for enterprises to manage social responsibility activities.

This article is divided into five parts. Firstly, it summarizes the research results at home and abroad and analyzes the connotation of strategic corporate social responsibility. Secondly, the paper studies the problems that should be paid attention to in the strategic management of corporate social responsibility, which provides the basic guarantee for improving the management efficiency of enterprise managers. Thirdly, it discusses the principles followed by the strategic management of corporate social responsibility, which provides guidance for the scientific implementation of the strategic management of corporate social responsibility. Fourthly, the paper puts forward the system design of the implementation of the corporate social responsibility strategy, which provides policy support for solving the problems in the enterprise strategic management. Finally, the paper summarizes the research results obtained in this paper and analyzes the future research trends.

\section{Literature Review}

The transformation of enterprise "economic man" to "social man" poses a new problem for managers who must not only consider the rights and interests of investors, but also pay attention to the reasonable appeals of consumers, employees, communities, and environmental stakeholders. It is not feasible to focus only on stakeholder interests while ignoring investors' interests or only focus on investors' interests while ignoring stakeholders' interests. To solve this conflict, we must build the benefit sharing mechanism between investors and consumers, employees, and communities.

In this context, domestic and foreign scholars try to build a strategic corporate social responsibility research framework. [1] firstly proposed the concept of strategic corporate social responsibility(SCSR) from the perspective of whether they can provide support for core business. They believe that only socially responsible behavior that can support core business is strategic. Following the idea of defining the concept, scholars have put forward different opinions, but most of them advocate that strategic corporate social responsibility is an initiative strategy that integrates social responsibility into the core values of the company and can create a competitive advantage [2]. There are also some scholars who disagree with the concept that corporate social responsibility behavior unrelated to the core business can change consumers' preferences for their products, expand product sales, and improve the economic performance of companies [3].

In order to provide corporate managers with a basis for decision-making, [1] firstly proposed a five-dimensional assessment method that defined the five 
characteristics that identify strategic corporate social responsibility, namely centrality, foresight, voluntariness, exclusivity, and visibility. [4] had built value chain models and diamond models of competitive environments, providing decision-making tools for selecting the best strategic CSR investment opportunities. [5] proposed a four-tier filtering method that provides analytical tools for selecting strategic corporate social responsibility. Wei Luo [6] designed a conceptual model consisting of a target filter, a focus filter, a commitment filter, an activity filter, etc., to distinguish between strategic and non-strategic corporate social responsibility activities. [7] systematically analyzed the research results of foreign scholars and found that they have done a lot of research on the benefit return mechanism of strategic corporate social responsibility. They believe that strategic corporate social responsibility can create corporate and social shared values by strengthening corporate strategies, enhancing corporate core capabilities, innovating business opportunities, and reducing social risks.

The existing research results on the definition, connotation and decision-making tools of strategic corporate social responsibility provide a certain reference for corporate managers. However, due to different research conclusions, it is inevitable that the enterprise managers will have problems in the process of implementing strategic management.

\section{Issues for Attention in Corporate Social Responsibility Strategic Management}

How to carry out the strategic management of corporate social responsibility has become an important topic in front of the leaders of enterprises. In order to improve management efficiency, enterprises must pay attention to the following basic issues in carrying out social responsibility activities.

\subsection{Don't Deceive Oneself as Well as Others: Give Full Attention to CSR Behavior}

One of the fundamental reasons for the unsatisfactory performance of Chinese corporate social responsibility is that corporate managers have different perceptions of corporate social responsibility behavior. Friedman's view that "corporate social responsibility is to seek maximum benefits for shareholders" can be described as deeply rooted. The core task of managers named "economic man" is to earn maximum profits for investors. Obviously, this view can no longer be adapted to the basic needs of the economy and society. Corporate managers must fully understand the strategic significance of social responsibility. It is precisely the wrong behavior of the enterprise managers to escape from fulfilling social responsibility. Chinese companies must assume due social responsibility obligations, such as economic responsibility and legal responsibility, in conjunction with their own economic strength. If conditions permit, they should strive to expand the scope of social responsibility at a higher level, such as charitable responsibility. Corporate managers must be aware of the fact that stakeholders 
are paying attention to the behaviour of corporate social responsibility and have high expectations of the company. Without their support, the company will be unable to move forward. With the improvement of living standards, consumers no longer need to "eat", but "eat well", they need high-quality products, harmonious communities, clean air and so on. Regardless of the legitimate interests of stakeholders, they will use their currency ballot papers to take companies off the stage.

Corporate managers should not assume that stakeholders do not pay attention to or have difficulty understanding the behaviour of corporate social responsibility. In this information explosion society, with the widespread use of social media, companies' every move is under the control of consumers. Therefore, business managers should not deceive oneself as well as others but should attach great importance to corporate social responsibility activities.

\subsection{Don't Attend to Trifles and Neglect Essentials: Understanding the Connotation of Corporate Social Responsibility Accurately}

Corporate social responsibility is a broad concept. Although the definitions are not the same, the basic meanings are basically the same. Caroll firstly proposed a pyramidal model of corporate social responsibility, including economic responsibility, legal responsibility, ethical responsibility, and charitable responsibility. Combined with stakeholder theory, corporate social responsibility has evolved into consumer responsibility, employee responsibility, community responsibility, environmental responsibility, and charity responsibility. Because of the wrong understanding of the meaning of corporate social responsibility, many corporate managers have not made the right choice. For example, some corporate managers believe that "corporate social responsibility is doing charity. "Charitable activities are one of the expressions of corporate social responsibility, but there are numerous cases where charitable enterprises do not necessarily fulfill social responsibility.

For example, the "Changchun Changsheng fake vaccine incident" that shocked the world, this problem may can infect children with all kinds of infectious diseases and further endanger the next generation of the motherland. The statement of "active participation in social public welfare undertakings" can be seen in the "Supplementary Announcement on the Full Annual Report of the 2017" of Changchun Changsheng Biotechnology Co., Ltd. We do not doubt its authenticity. However, the company violated its "people-oriented, scientific and technological innovation" corporate philosophy and "care for life, sowing health" corporate purpose. The wrong choice of behavior has brought fatal and overwhelming disaster to the company. Therefore, for enterprise managers, it is the basic requirement to accurately grasp the connotation of corporate social responsibility.

\subsection{Don't Incorrectly Estimate Your Own Strength: Actively and Selectively Fulfill Social Responsibilities}

The core meaning of corporate social responsibility is to pursue the realization 
of other social responsibility categories based on the pursuit of economic responsibility, that is, profit is the primary social responsibility of enterprises. Enterprises should selectively fulfill their social responsibilities around the fundamental goal of profit. For example, for small enterprises, they should more often pursue economic and legal responsibilities, while for large enterprises, they should contribute to charity, environmental protection, etc. Selective performance is not the choice of "not fulfilling", but choosing "how to perform". Different sizes and ownership of enterprises should be different in the choice of social responsibility strategies.

To correctly choose the corporate social responsibility strategy, the manager must understand that, first of all, the unprofitable enterprise cannot fulfill social responsibility well. Overloading the social responsibility will increase the operating costs of the enterprise, which may bring more market risks to the enterprise due to the problem of capital turnover. Therefore, regardless of the nature of the enterprise, profit is the basic goal of the enterprise. Secondly, no matter what kind of enterprises can perform social responsibility well. Corporate social responsibility should run through the whole process of production, decision-making and operation, and everyone is required to attend. For those enterprises with limited profitability, and the provision of high-quality products that meets the expectations of consumers is also the performance of social responsibility. Therefore, enterprises must not incorrectly estimate your own strength and do some "opportunistic social responsibility", lifting a rock only to drop it on your own feet. Finally, enterprises should actively carry out corporate social responsibility activities in conjunction with their core business. Enterprises engaged in social responsibility activities that have nothing to do with the core business will bring greater risks to enterprises.

\section{Basic Principles to Follow in the Management of Corporate Social Responsibility Strategy}

It is only after an accurate understanding of the problems that should be paid attention to in the strategic management of corporate social responsibility that the managers can effectively carry out the strategic management activities of corporate social responsibility. We firstly discuss the basic principles to be followed in the strategic management of corporate social responsibility.

\subsection{Balance Principle}

Whether it is based on the "triple bottom line theory" proposed by British scholar John Elkington, Carroll's corporate social responsibility hierarchy model, or the multi-dimensional social responsibility model under stakeholder guidance, managers must follow the principle of balance between the CSR categories, That is, corporate managers must find a balance point between economy responsibility, environment responsibility, and society responsibility. Enterprises managers must grasp which CSR is feasible, understand the interconnections between so- 
cial responsibility categories, and comprehend exactly which social responsibility categories can be realized or cannot be achieved through efforts, taking into account their own economic and social environment. It is clear that the balance point between the various categories of corporate social responsibility varies by size or ownership. Some companies have made considerable achievements in environmental protection; some companies are committed to solving the employment problems of employees; some companies focus on improving the quality of their products.

\subsection{Process Principle}

The strategic management of corporate social responsibility is a systematic management process, which should be carried out in an orderly manner according to the strategic analysis $\rightarrow$ strategic choice $\rightarrow$ strategic implementation $\rightarrow$ strategic control process. Enterprises must follow this principle in fulfilling social responsibility.

The fundamental purpose of the strategic analysis is to identify the key factors affecting current and future developments and to rank specific impact factors by importance. Firstly, managers must combine the actual establishment of the enterprise mission and vision. It is impossible to establish a CSR development strategy without an objective, and the vision and objectives are the basis for strategic analysis. Secondly, to find out the internal and external environmental factors that affect the future implementation of the corporate social responsibility strategy, SWOT analysis method can be used in the analysis of the influencing factors. Strengths and weaknesses are analyzed in the internal environment of the enterprise, while opportunities and threats are more concerned with the external environment.

The strategic choice is a strategic plan and action formulated after the strategic analysis, based on the internal and external environmental factors faced by the enterprise, and under the limited resources, making full use of strengths and opportunities, and avoiding weaknesses and threats. This part should not only establish the objectives of enterprises to implement social responsibility strategies, but also establish priorities for the implementation of social responsibility categories. The process of CSR strategy selection is related to the work plan of the future enterprise for several years. Once the problem of strategic choice arises, the impact on the enterprise is very bad. Strategic choices can be carried out in accordance with the process of "developing options $\rightarrow$ evaluating options $\rightarrow$ selecting final options". Each link must be fully demonstrated and implemented carefully.

Strategy implementation refers to the process of translating the selected strategy into action following the plan, which must be under the leadership of the senior managers of the enterprise, and all members must participate together. The resource allocation and organization structure design of the enterprise must revolve around the enterprise strategy. 
Strategic control is to compare and analyze the information returned during the implementation of the social responsibility strategy with the strategic objectives. If there is a deviation, adjustment measures can be adopted. In this link, it is very important to scientifically implement the evaluation system or evaluation criteria of social responsibility strategy. Too high or too low standards are not conducive to the implementation of corporate social responsibility strategies.

\section{Institutional Design for Implementing Corporate Social Responsibility Strategy}

According to the principle of balance and process, enterprise managers can work out the relevant system of corporate social responsibility and guarantee the implementation of corporate social responsibility strategy.

\subsection{Building Synergies between Social Responsibility Strategies and Core Business}

The corporate social responsibility strategy, which is selected according to the internal and external environment of the enterprises, must be integrated with the core business, and the synergy between the two must be fully realized. While realizing the economic goals of the enterprise, it can better take into account the realization of the social goals and eventually form the continuous competitive advantage of the enterprise.

\subsection{Establishing Lead Agency for the Implementation of Corporate Social Responsibility}

In order to ensure the implementation of corporate social responsibility, it is necessary to establish an authoritative leading institution. Enterprises can set up a corporate social responsibility strategy committee. The chairman of the company serves as the chairman of the strategic committee and strategically directs the corporate social responsibility practice activities. The strategic committee has a specific organizational implementation agency and identifies the specific responsible person.

\subsection{Constructing the Reward and Punishment Mechanism to Guarantee the Implementation of Corporate Social Responsibility}

The corporate social responsibility strategy is a systematic project. The reward and punishment mechanism should run through the whole process of enterprise strategic management, and individuals who perform more prominently in each link should be rewarded. For those individuals who have problems in the strategic management of corporate social responsibility, due punishment should be imposed, otherwise the reward and punishment mechanism will be ineffective.

\subsection{Establish Scientific Social Media Usage Code}

For companies, social media is a double-edged sword. Poor use may cause great 
trouble for enterprises, and good use can produce a larger brand shaping effect. Through social media, companies can promote their social responsibility activities, and attract the attention of stakeholders, laying the foundation for the formation of corporate brands. However, corporate managers must establish a scientific social media usage code and strictly require corporate employees to regulate the use of social media.

\section{Conclusion and Directions for Future Research}

By analyzing the existing problems and the principles in the strategic management of corporate social responsibility, it not only clarifies the perplexity before the managers of enterprises, but also provides guidance for the managers to implement the strategy of corporate social responsibility scientifically.

This paper analyzes the principles followed in the implementation of social responsibility strategy management by means of normative analysis, and puts forward some pertinent policy suggestions. However, the current research cannot provide sufficient evidence to support the implementation of social responsibility. The comparative studies with developed countries of the implementation of corporate social responsibility strategies are likely to become new research issues, which can become the experience learning for the developing country.

\section{The Possible Innovations of This Paper}

According to the National conditions of China, it is a new attempt and exploration to put forward the principles that Chinese enterprises should follow in implementing social responsibility strategy and discuss the process of strategic decision-making.

\section{Project Funding}

Henan Province Philosophy and Social Science Planning Project "Research on Strategic Corporate Social Responsibility Value Creation Mechanism Based on Social Media" (No. 2016CJJ081). Project for the Training of Young Cadre Teachers in Henan Higher Education Institutions "Research on the Value Creation of Strategic Corporate Social Responsibility in the Context of Social Media" (No. 2016 ggjs-132).

\section{Conflicts of Interest}

The authors declare no conflicts of interest regarding the publication of this paper.

\section{References}

[1] Burke, L. and Logsdon, J.M. (1996) How Corporate Social Responsibility Pays Off. Long Range Planning, 29, 495-502. https://doi.org/10.1016/0024-6301(96)00041-6

[2] Qi, Y.S. and Huang, Z.D. (2014) The Relationship between Strategic Corporate So- 
cial Responsibility, Open Innovation and Corporate Performance. Reform of Economic System, No. 6, 116-120.

[3] Chernev, A. and Blair, S. (2015) Doing Well by Doing Good: The Benevolent Halo of Corporate Social Responsibility. Journal of Consumer Research, 41, 1412-1423. https://doi.org/10.1086/680089

[4] Porter, M.E. and Kramer, M.R. (2006) Strategy and Society: The Link between Competitive Advantage and Corporate Social Responsibility. Harvard Business Review, 84, 78-92.

[5] Bhattacharyya, S.S. (2010) Exploring the Concept of Strategic Corporate Social Responsibility for an Integrated Perspective. European Business Review, 22, 82-101. https://doi.org/10.1108/09555341011009025

[6] Luo, W. (2011) Conceptual Model Construction of Strategic CSR Activity Recognition. Commercial Times, No. 1, 59-61.

[7] Wang, S.N., Hu, S.S. and Qian, X.J. (2011) Probe into the Future of Strategic Corporate Social Responsibility Research. Foreign Economics \& Management, 33, 57-64. 